\title{
Optical Measures: A Design Tool to Attain Truth or Illusion?
}

\author{
Ufuk Soyöz ${ }^{1}$
}

Published online: 21 June 2015

(C) Kim Williams Books, Turin 2015

\begin{abstract}
The optical measures have often been explained within the conceptual framework provided by Vitruvius: the "true" symmetries are distorted by space. Hence they have to be corrected by optical measures under the "real" conditions of appearance. While scholars have studied the phenomenon of optical measures within a narrowly mathematical framework, the aesthetic implications of Vitruvius' claim, his ambiguous use of the "truth" and "reality" has hardly been noticed. By situating the phenomenon of architectural proportions within the broader aesthetic discourse on Hellenistic art, this paper shall reveal the paradox of discourse between the optical knowledge and professional power of the architect. Rather than being a means to a quintessential truth or reality, the paper shall demonstrate how indeed optical measures were employed as a means to stylistic ends; that the change in the proportions of temple architecture from the Classical to the Hellenistic age predicates a painterly taste.
\end{abstract}

This article grew out of my doctoral dissertation, Drama on the Urban Stage. Architecture, Spectacles and Power in Hellenistic Pergamon (The University of Texas, 2010), written under the advisorship of John R. Clarke and Penelope J. E. Davies. I am glad to be able to acknowledge here an enormous debt of gratitude to them. I extend special thanks to Nexus Network Journal's anonymous reviewers and the participants of Nexus Network Conference 2014 in Ankara who offered many insightful comments for improvement of this paper. I am also grateful to John R. Clarke and Rabun M. Taylor for illustrations. My doctoral research in Hellenistic Asia Minor was funded by a Samuel Kress Foundation Travel Grant and grants from the University of Texas. My current research, including preparation manuscript images (photo-collages by Hasan Gökbora) is funded by a European Commission Marie Curie Career Integration Grant.

Dr. Ufuk Soyöz

ufuk.soyoz@kemerburgaz.edu.tr

1 Department of Interior Architecture and Environmental Design, Istanbul Kemerburgaz

University, Mahmutbey Dilmenler Caddesi No: 26, D Blok No: 419, Bağcılar, Istanbul, Turkey 


\section{Introduction}

Optical measures, such as curvature, entasis and other Greek temple refinements were broadly defined as subtle deviations from the straight outline and surface, from the strictly vertical and horizontal arrangement of forms, and from the equal dimensions of similar elements. Barely noticeable to the modern eye, the curvature of stylobate and entasis, contraction, inclinations, and enlargement of columns were already known from Vitruvius. When the physical evidence for such measures was found at the Parthenon in the early 1830s, a heated debate rose within the scholarly community, primarily on the intentionality of optical measures and secondarily on their origins, purpose, effects and meaning. These issues had up to that point been primarily considered within an architectural and mathematical discourse. Building upon Haselberger's recent inclusion of optical measures within the broader Vitruvian concept "detractions and additions", optical measures will be considered here within an interdisciplinary artistic and philosophical discourse comprised of painting and sculpture, and in an historical sequence extending from the Classical to the Hellenistic period (Haselberger 1999, pp. 1-56). Throughout this discussion, I will demonstrate how the application of curvature, entasis, and proportional adjustments in architecture resulted in a shift from a sculptural (i.e. corporeal) to a painterly taste. For the purposes of this argument, I define the change from sculptural to painterly taste in mathematical terms. From the Classical to the Hellenistic age optical measures came to be employed to emphasize depth rather than mass: the bulging of columns became less prominent, the columns became more slender and the spacing between them became wider.

Before demonstrating the trend, it is necessary to draw the outline of artistic discourse leading to such a significant stylistic transformation. Ancient discourse on optical measures, closely linked with the discussions on canons of proportions in architecture and sculpture, was founded on the existential paradox of the truth and illusion. Furthermore, the paradoxical nature of the ancient dichotomy between truth and illusion was given by the Platonic distinction between corporeal arts (architecture and sculpture) and painting. According to Plato, on the one hand all art forms are considered a mimesis of nature, hence illusory; on the other hand threedimensional architecture and sculpture was deemed more "true" than twodimensional painting. I will argue that the contradiction inherent in this statement affected the visual integration of architecture and painting through the application of optical measures and painterly perspective (skénographia). The truth, or corporeality, of three-dimensional art in the Classical age was gradually replaced by the "illusion", or painterly forms of expression, of the Hellenistic period. So perspectival developments in both fields resulted in a unified field of vision empowering artists and architects twice over: firstly, because it enabled them to construct a blurred (inter-disciplinary) reality (between the architectural and painterly hence real and imaginary) and secondly to present their preferred (blurred) aesthetic taste as the real, i.e. natural consequence of the application of optical science to architectural proportions and painting. 


\section{Ancient Discourse on “Truth" Versus “Illusion"}

The paradox of truth and illusion is related to a family of paradoxes concerning dream and waking life, appearance and reality (Leiber 1993). The paradoxical observation is that there is no way one can tell whether the physical world, oneself included, is real or merely a dream. This question is enchanting and dizzying at the same time since it keeps the individual in the loop of contradiction while engaging with the existentiality of being human. If a piece of art or architecture makes the viewer ask this question, then it has created a desirable outcome for its artist as it engages the attention of the viewer longer than any question answerable with logic would.

While we as moderns experience the unpleasant confusion that a paradox causes as an occasional computer crash or as an enchanting dizziness in front of a neorealist artwork, ancients in the late Hellenistic cities, such as Pompeii, saw the paradox (truth vs. illusion) visualized as a collapse of the boundary between architecture and painting; between two and three dimensions (Figs. 1, 2). We can observe such a unified field of vision, for instance, in the combination of the painted architecture of the House of Menander and the wall painting from the Villa Oplontis. Of course, the initiated observer could differentiate the embodied experience of architecture from the shallow representative depth of the wall painting, but the initial perception of a similarity between scale and proportions, space and color would lead to a momentary collision between architecture and painting, depth and surface, truth and illusion, the permanent and the fleeting. In other words, in the ancient world the paradox of truth and illusion was intimately connected to the lived experience of architecture, sculpture and painting. My argument is that what led to such a fusion in the languages of visual arts was tied to the prior Platonic opposition of architecture and painting consecutively in the realms of truth and illusion. Such a paradoxical distinction was gradually erased by

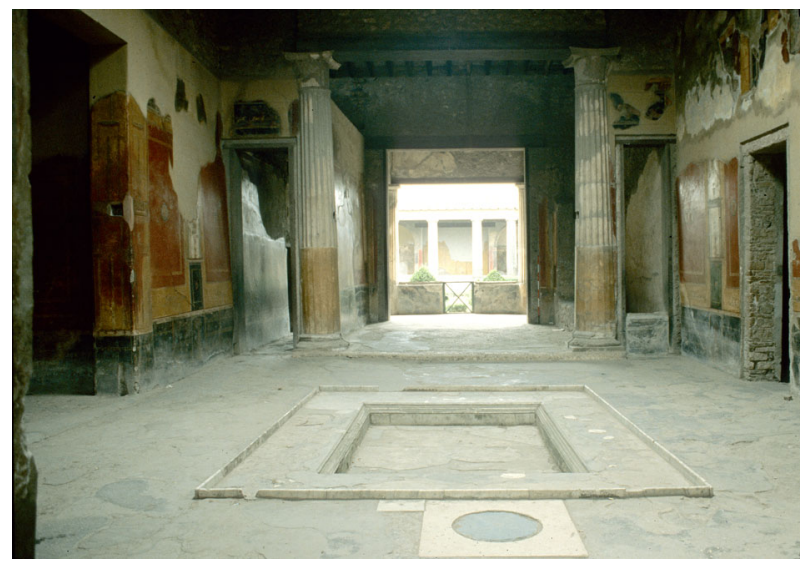

Fig. 1 House of Menander. View from Fauces through Atrium. c. 3rd century-1st century BCE C John R. Clarke 
Fig. 2 Villa di Poppea.

Triclinium 14. North Wall. c. 50-10 BCE @ John R. Clarke

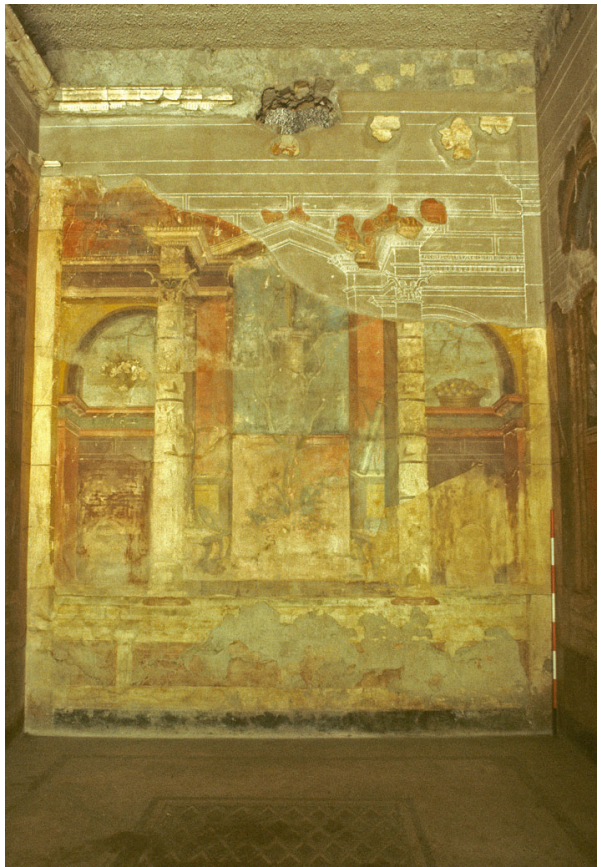

architects' adoption of a painterly language (and painters' adoption of a threedimensional language) by means of Euclidian Optics. This paper shall deal primarily with the architectural adaptation of painterly language by means of "detractions and additions" (including optical measures) made to the proportions.

Architects' adoption of painterly language was closely tied with another Platonic paradox that required applications of optical measures into architecture, sculpture and painting. In addition to classifying fine arts as true or illusory depending on their dimensional medium, Plato (2005) also judged architecture and artworks as true or illusory with respect to their proportions. Plato (2005) was the philosopher who cast the very notion of "true proportions" and "those which seem to be beautiful" into opposition. Plato (2005) accused artists, who create "large work of sculpture or painting". If they did follow true proportions "the upper parts would seem smaller and the lower parts larger than they ought because we see the former from a distance, the latter from near at hand." Thus the artists "abandon the truth, and give their figures not the actual proportions but those which seem to be beautiful" (Sophist 235E).

While in the above quote Plato (2005) does not specify which works he praises as having "true proportions" - as opposed to "those beautiful in appearance"-from his Euclidian framing and from the artistic manifestoes of his contemporaries we can extrapolate his "taste". The Platonic paradox of "true" and "beautiful" proportions constitutes the basis of an interdisciplinary artistic discourse; a system of binary oppositions centered around proportions. By utilizing Platonic pairs, such as truth [ideal, real] and illusion [beautiful, real], often in quite contradictory interpretive positions, dramatists, artists and architects assert the 'truth value' of 
their works, claiming discursive dominance against their rivals or predecessors. ${ }^{1}$ While artists from the generation of Plato (2005) favor "true" proportions, his successors claim to use optical tools to achieve beautiful proportions, i.e. "those true in appearance". For instance, Polykleitos articulates "The Canon" that represented men according their true (ideal) proportions, while Lysippos outdoes his predecessor with a new canon that produced men who seem real; "true" in the eye of the beholder. ${ }^{2}$ We learn from Pliny (NH 34.65) that Lysippos was proud to be praised for his achievement of finally representing men "as they appear to be", whereas "the ancients made men as they really were".

What Pliny also tells us is that Lysippos aspired to incorporate a new set of proportions into his statues which took appearance into account. Lysippos criticized the older canon of proportions, most likely referring to Polykleitos' famous creation, the Doryphoros, a work that was sometimes simply referred to as "the Canon" (Pollitt 1986, p. 47). Contrary to the Doryphoros, which represented men according to their true proportions, Lysippos devised a system that takes the appearance of the object in the eye of the beholder into account. The contrast that Lysippos established between his canon and "the Canon" of Polykleitos translates as a distinction Plato (2005) articulated between "true" and "apparent" symmetries. Lysippos does not simply want his statues to be tall; he wants them to seem tall, and modifies their proportions to achieve this effect.

The occurrence of a similar shift in architectural proportions from the Classical to the Late Classical period was recorded in Philon's late third century BC treatise. ${ }^{3}$ Like Lysippos, Philon discusses the importance of appearance and its consequences for architectural design by explaining one of the already established principles in the field of architecture: the method of "adding and subtracting to and from the masses" and shaping them, by diminution, in a "mouse-tailed" way, because the eye is not the same distance from all parts of a work, and hence is deceived. Philon continues that one has to learn to render architectural elements not "equally dimensioned and vertical in reality" as was the case with "the old, excessively artless" works; rather one should avoid seemingly uneven dimensions and arrangements by working out "a balanced and well proportioned" appearance to the eye. ${ }^{4}$

When Vitruvius explains the reason for the use of optical measures, he employs similar terminology and method of explication. According to Vitruvius, the concept of "detractions and additions", detractiones et adiectiones, (the slight modifications of measurements in order to adjust the proportioned dimensions of a work), was necessary to achieve eurythmy, "the beautiful appearance [venusta species] and

\footnotetext{
1 The same discussion also has a theatrical counterpart as an opposition between Sophokles and Euripides. Sophokles, for instance, claims to have "created characters as they ought to be", (i.e. true to an ideal) while Euripides "as they really are" (true to reality). Aristotle, Poetics (2005) 1460 b $35 \mathrm{f}$.

2 Pliny, Natural History (2005) 34.65. While Pliny does not specify Polykleitos as Lysippos' rival, instead referring to "the ancients who made men as they are", the scholarly consensus is that he meant to alter Polykleitos' Canon. On Lysippos, see: Moreno (1973); Filseck (1988), p. 280ff; Edwards (1996), pp. 130-153, esp. 132f; Pollitt (1974) (note 225) p. 29; Pollitt (1986), p. 47f.

3 Philon's treatise on artillery with translation and detailed commentary, see Marsden (1971), pp. 105-184.

${ }^{4}$ Philon's passage on architectural design in Belopoika 50.30-51.7 (ed. Marsden).
} 
fitting aspect of the parts in composition." 5 The architect must strive for "beautiful appearance" by adjusting or "tempering" proportions so as to flatter the eye of the beholder. ${ }^{6}$ Vitruvius explains why it is important to apply such modifications in private houses (6.2); and why the task requires not just rules, but the "ingenium and acumen" of an architect. ${ }^{7}$ According to Vitruvius, the modifications are necessary, because the true and real symmetries, the verae symmetriae (6.3.11) are not to be relied on but only the adjusted ones-modified under the actual conditions of appearance limited by space and the deceptive nature of the human eye: "For the eyes do not bring accurate results, but the judgment is often deceived by it" (6.2.2). Vitruvius continues: "the vision of the eyes gives false judgments... what is true seems false...". The symmetries adjusted by detractiones et adiectiones, on the other hand, create impressions in which the proportions appear "in harmony with verae symmetriae" (6.3.11).

As seen in the quotations above, both sculptors like Lysippos and architecttheoreticians like Philon and Vitruvius build on the Platonic paradox: truth versus illusion. Unlike Plato (2005), who, without a resolution at hand, laments distortions that might lead to false judgments, Lysippos, Philon and Vitruvius find a solution in optical science: to adjust sculptures or architectural elements with respect to their appearance, i.e., the distance between the object and the eye of the beholder. Modified under the actual conditions of appearance, limited by distance and the deceptive nature of the human eye, apparent proportions shall appear "correct" in the eye of the beholder.

But what do these apparently correct proportions look like? In sculpture, the question is easier to answer. The classical Canon is taken at a certain point to be that of Polykleitos, which is then replaced by that of Lysippos, who took into account appearance. He did not want his sculptures to be tall, but to seem taller than they actually are. We could actually observe such a transition from the solidity of Doryphoros of Polykleitos to the leaner figure of the Spear Bearer by Lysippos (Figs. 3, 4). In architecture a similar notion is put forward by Philon and Vitruvius. While they did not describe what makes a temple "apparently beautiful" as opposed to "simply correct", their terminology considered together with Platonic oppositions of truth versus illusion, and architecture versus painting, suggest a shift towards a painterly style adopted by Hellenistic architects. The visual evidence for such a style evolving as a consequence of optical thinking and the criteria for a new

\footnotetext{
5 Vitruvius, On Architecture (2005) 1.2.3: "Eurythmia est venusta species commodusque in compositionibus membrorum aspectus." (eurhythmia, in Greek; literally "well-shapedness"). Translations of Vitruvius throughout the text unless otherwise indicated are from The Loeb Classical Library edition by Frank Granger. For the translation above of eurythmia, see Pollitt (1974), pp. 144-145; on the concept of eurythmia in general, see Pollitt 143-154; Bek (1985).

${ }^{6}$ For standard modifications of architectural elements and their numerical rules esp. Vitruvius 3.3.11 (thickening of corner columns); 3.3 .13 (varied diminution of columns); 3.5 .8 (adapted height of architraves); 3.5 .13 (inclination of all elements of entablature); 4.4.2 $\mathrm{f}$ (different thickness of columns in interiors).

7 Vitruvius On Architecture (2005) 6.2.1: acuminis est proprium...; 6.2.4: ingeniorum acuminibus, non solum doctrinis; 6.3 .11 : ingenio et acumine.

8 Vitruvius On Architecture (2005) 6.2.3f: falsa iudicia oculorum habeat aspectus...quaesuntvera, falsa videantur....
} 
Fig. 3 Doryphoros from Pompeii. After Polykleitos. Roman copy of the Greek original (c. 440 BCE). Naples National Archaeological Museum photo by Marie-Lan Nyugen (C) Creative Commons

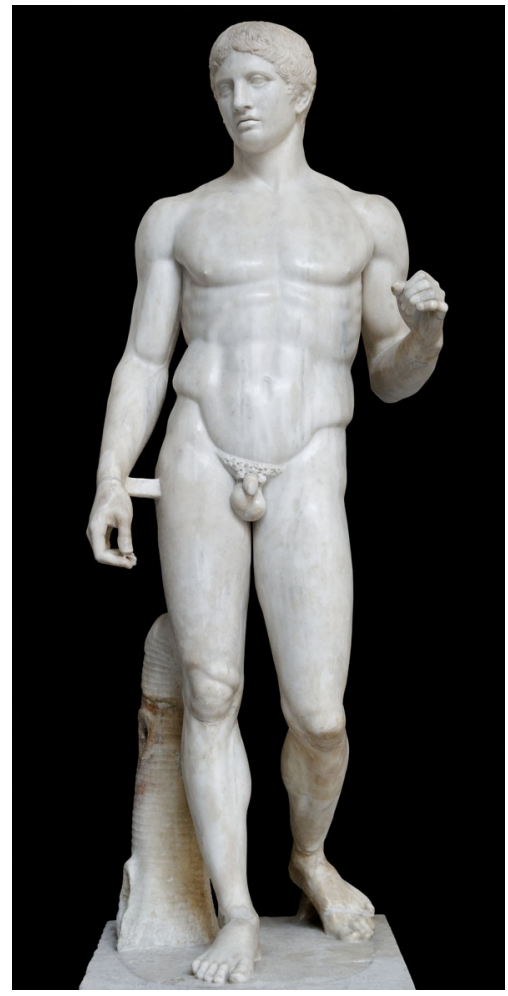

canon that would enable the achievement of a painterly appearance will be demonstrated in the following section.

\section{Optical Measures}

It should come as no surprise that modern antiquarians and architects who discovered optical measures were trapped in the ancient debate over truth and illusion. Barely visible even under close observation, when the curvature in the Parthenon's stylobate was first noticed by German architects it was existentially questioned. Were the curves intentional or accidental [Bötticher 1806-1809]? Did closely approximated lines that constituted curves occur due to the ruinous state of the monument or as the result of design? Eventually, the intentionality of the curvature was widely agreed upon. Even then, the purpose of the measures was still connected to the debate over truth and illusion. Based on a passage in Vitruvius, the curves of Greek architecture were initially interpreted as optical corrections of illusory effects. In this passage, Vitruvius refers to curvature as the "addition in the stylobate" [stylobatis adiectio (5.9.4)] and explains the details of constructing this "addition": 
Fig. 4 Apoxymenos. After

Lysippos. Roman copy of the Greek original (c. 330 BCE)

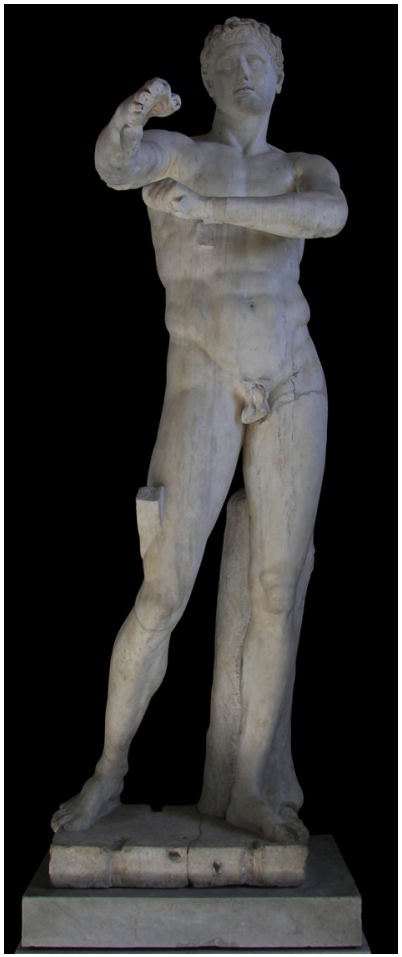

Stylobatam ita oportet exaquari, uti habeat per medium adiectionem per scamillos inpares. Si enim ad libellam dirigetur, alveolatus oculo videbitur (3.4.5).

[The stylobate must be horizontally adjusted in such a way that it has an addition toward the middle by means of scamili inpares. If the line of the stylobate were perfectly horizontal, it would appear hollow like the bed of a channel]. ${ }^{9}$

Vitruvius' description gave rise to popular modern belief that optical measures were meant to correct the deceptive perception of the human eye. Since "a long straight line above the eye tends to seem curved downward in the middle", the upward curvature of the entablature was meant to appear horizontal. In other words, the curvature was meant to "correct", the sagging impression experienced by the beholder looking upwards (Choisy 1999 [1899], p. 184).

While Vitruvius' passage initially led to the generalization of his explanation as being based in an understanding that regularity, linearity and mathematical correctness were the purpose of optical measures, it is important to emphasize that Vitruvius probably did not mean to argue for a mathematical linearity when he explained the purpose of the "addition in the stylobate" as a corrective measure. ${ }^{10}$

\footnotetext{
9 For the translation and on problems of the translation of Vitruvius, see Haselberger (1999), pp. 4, 36f.

10 Goodyear (1912), pp. 33-68 was the first modern scholar to argue against corrective purpose of optical measures. Instead of "corrections," he coined the term "refinements" and demonstrated that Greek refinements were used as means to various ends (Goodyear 1912, p. 19).
} 


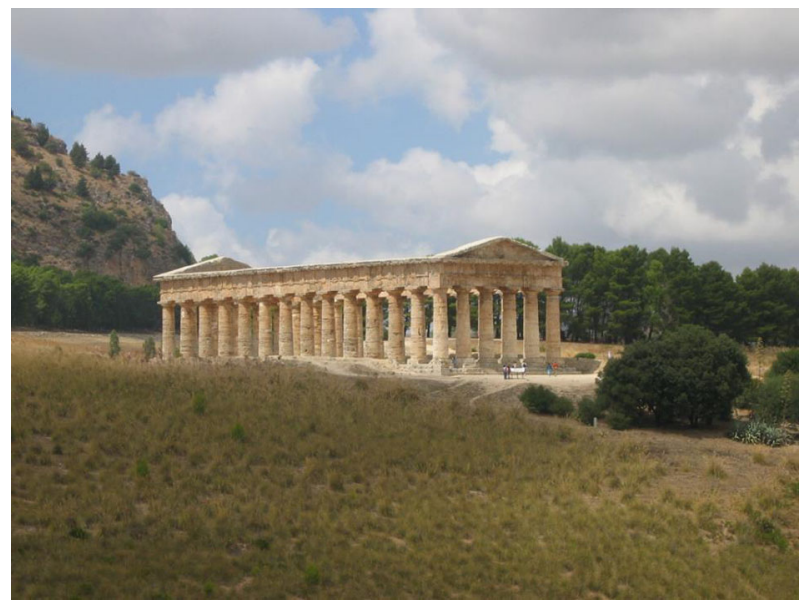

Fig. 5 Archaic Temple of Segesta. C. 420 BCE (C) Creative Commons

His aim might have rather been the promotion of an appearance of horizontality that was fitting to his painterly taste. Such a linear appearance was probably meant to deny gravity, the existential load-bearing capacity of architectural elements, and meant to represent architecture as if it were a painting. Such an appearance was contrary to the ideals of previous periods. As already noticed by Goodyear and others, the curvature of stylobate and entasis of columns were intentionally exaggerated in most early Greek temples. At the Temple at Segesta, for instance, the upward bulging stylobate seems to be an intentional preference for a sculptural expression of corporeality (Fig. 5). Here, the architecture was not linear like a "painted" element but comparable to a sculpture acting under load like a muscle in action within the body of an edifice's structure. Such corporeality seems a desired archaic quality, an expression of aliveness.

The diminishing sculptural quality of Greek temples becomes apparent if we follow the sequence of temples built from the mid-fifth century onwards. In the following, I will demonstrate how the application of curvature, entasis and proportional adjustments in architecture resulted in a shift from a sculptural (i.e. corporeal) to a painterly taste. This shift occurred in parallel with the Hellenistic preference for Ionic style, which could be described as painterly in comparison with the sculptural Doric.

\section{Curvature}

Curvature, using extremely fine and elongated curvilinear lines (or of closely approximated polygonal lines), is applied to masonry buildings from their foundation to roof in such a way that every seemingly horizontal line, surface and stone course forms a slight curve away from the [true] straight line or plane. The curve is often set at the foundation of the building as the "addition on the 
stylobate", stylobatis adiectio (5.9.4) and carried through all the courses of the building in the construction process. As such, curvature was a corporeal phenomenon.

The earliest Greek buildings showing curvature were the mid-sixth century Temple of Apollo at Corinth, the Old Temple of Athena on the Akropolis, the early fifth century Temple of Aphaia at Aigina, the Older Parthenon, followed by the Temple of Zeus at Olympia and shortly after the mid-fifth century, the Parthenon (Fig. 6). The sequence of Doric mainland buildings confirm the traditional viewpoint that curvature was intrinsically a sculptural means of expression comprising all parts of a structure. A watershed in the application of the curvature was the Propylaia (Fig. 7), modeled on the design of the Parthenon, yet unlike the Parthenon in that the Propylaia displays a selective use of curvature. While curvature was previously a corporeal measure utilized in all parts of a structure from platform to roofline, at the Propylaia it was applied selectively. The stylobate of the Propylaia, both at the center and wings, is horizontally levelled, while the horizontal lines of the entablature were curved in the central porticoes of its two fronts. The increment of curvature is produced by an addition made to the height of the central columns. Such an adjustment seems to be designed to correct the sagging effect in the middle of the entablature to be seen by the visitor approaching the entryway from the central axis. Such an apparent horizontality might have been appealing to a painterly aesthetic aiming to shape the perception of the entrance portal as a flat background rather than a three-dimensional architectural body (Fig. 7).

Another changing trend in the application of curvature from the Classical to the Hellenistic period was the relative ratio of the curves' rise within a temple (Haselberger 1999, pp. 180-183). Curvatures of the fifth century and some of the fourth century temples show a consistent feature in the distribution of the curves. The rise of the curves is either more pronounced on the front in comparison with the sides or they are equal (Haselberger 1999, p. 182 (Table 9.1)). In Hellenistic monuments on the other hand, we observe side curvatures two times greater in

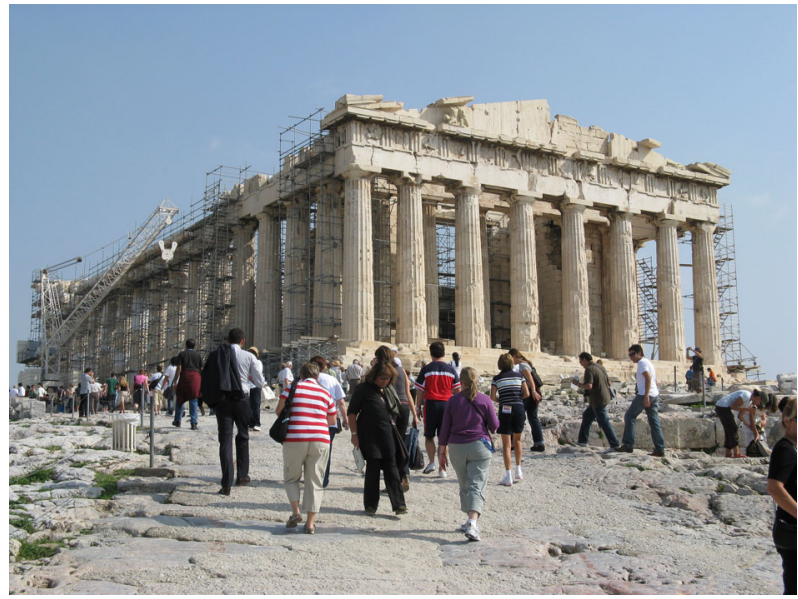

Fig. 6 The Parthenon, Athens 


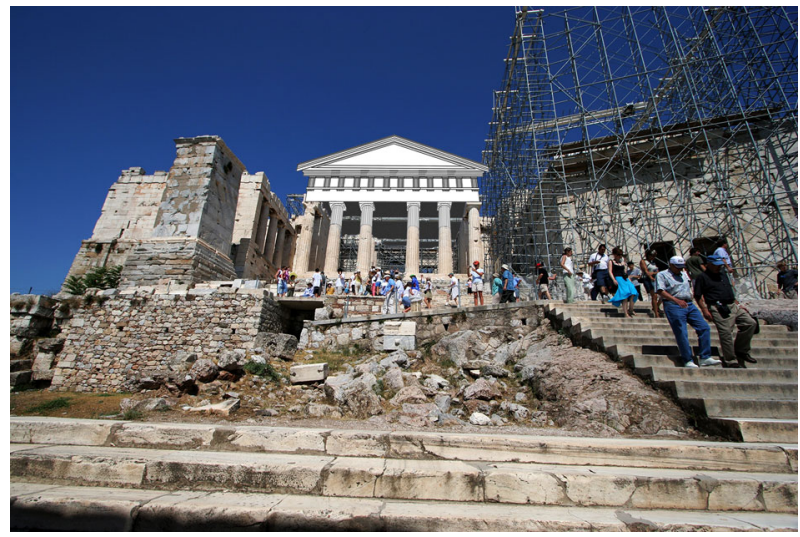

Fig. 7 The Propylaia, Athens, photo by Rabun M. Taylor, photo collage by Hasan Gökbora CUfuk Soyöz

comparison with the front. Such a consistent change might have been guided by the change in the positioning of the temple. Fifth and fourth century monuments were positioned to be seen as sculptural objects in the sense that the three corners of each building were visible from the main entrance of the site (Fig. 6). In other words Classical temples, such as the Parthenon, were displayed within an angular viewpoint. ${ }^{11}$ Hence the equal rise of their curvature on the front and the sides or the emphasis on the front with respect to the side curvature might have been designed depending on the radius of the viewing angle. Hellenistic buildings however began to be displayed and approached frontally on specifically designed linear axes so that only the front of the temple was seen as a flat façade. In that case the doubly emphasized curves at the sides might have been meant to increase perceived depth of the temples' appearance (Haselberger 1999, pp. 18-183).

\section{Entasis}

Entasis denotes the slight swelling in the outline of column shafts or, occasionally, of other supports such as anta piers, pilasters or even walls. Vitruvius informs us that "an addition in the middle of the column", adiectio in media columna (3.5.14), "among the Greeks is called entasis", (3.3.13). Entasis is a vertical curvature. While entasis and curvature were not strictly interdependent (entasis sometimes applied without curvature, for instance in the Erechtheion) their formal parallelism suggests a degree of closeness of intention. The similarity of intention is also

\footnotetext{
11 According to Doxiadis (1972) Classical Greek temples were laid out according to polar coordinates and the determining factor in design was human perception. After analyzing 20 sites he comes up with certain principles: (1) Each site was designed according to a main vantage point, which was the main entrance to the whole site. (2) Radii from the vantage point determined the three corners of each important building. (3) These radii were determined by mathematical division of the viewpoint into equal portions (360 degree is either divided into 10 or 12 parts). This system gradually changes towards an axially planned layout during the Hellenistic period.
} 
supported by the ancient term entasis itself, which means "tension" or stretching. ${ }^{12}$ The term seems to express quite literally the structural role of the column acting under a load, responding to its task of carrying the structure. The distortions are thus more likely to be an expression of the architectonic elements as corporeal forms, emphasizing their function as load-bearing architectural elements.

The expression of such a corporeal function is at its most prominent in the earliest occurrence of known entasis in the archaic temples at Paestum (Fig. 8). Visible in all three grand temples of Paestum, reaching $4.8 \mathrm{~cm}$ over $51 / 2 \mathrm{~m}$ or about $1 / 100$, the swelling of their columns creates the visual impression of conscious exaggerations. Significantly enough, such obvious expressions of muscularity were found distasteful by Winckelmann, who asserted in 1762 that as an unpleasant "belly giving no grace to columns", entasis was not used in good Greek buildings (Winckelmann 1964 [1762], p. 21). It should come as no surprise that being one of the pioneers of the Neoclassical movement, like Vitruvius, Winckelmann preferred the Classical style of Athenian monuments, such as the Parthenon, which he assumed not to demonstrate entasis. ${ }^{13}$ By the time the Parthenon, Propylaia and the Erechtheion were built in the Classical period, the slight curves in columns had become more subtle. In the pronaos columns of the Parthenon, the rise is only c. $2.4 \mathrm{~cm}$ over c. $9.40 \mathrm{~m}$ or $1 / 400$, and in peristyle columns the rise is about $1.6-1.7 \mathrm{~cm}$ over a shaft length of c. $9.60 \mathrm{~m}$, c. 1/550-1/600 in relative terms (Haselberger 1999, p. 28, n. 94). In the interior Ionic columns of the Propylaia the rise is only $6 \mathrm{~mm}$ over a shaft length of $9 \mathrm{~m}$, and is the softest columnar entasis known. Likewise the curve of the Ionic columns of the Erechtheion's North Portico, with a maximum rise of just $6 \mathrm{~mm}$ over a shaft length of $6 \frac{1}{2} \mathrm{~m}$ formed one of the gentlest curves which has ever been applied to any architectural line. Especially in the last two examples, the purpose of entasis is clearly to elongate the column length, diminishing their sculptural quality almost to the point of denying their reality as load-bearing elements.

While we can notice a general trend towards more subtle use of entasis in temple architecture during the transition from the Classical to the Hellenistic period, Doric to Ionic style, this is not always the rule. The rise of entasis was rather designed with respect to optical rules, i.e., the viewing angle and the distance of the viewer from the object. That must be the reason why we see a very slight curve in the walls of the Parthenon, about a $3 \mathrm{~mm}$ rise over $9 \mathrm{~m}$, approximately $1 / 3000$, since the curve could only be perceived at a very close distance by the viewer standing inside the Parthenon peristyle. Another exception to the rule is the Temple of Apollo at Didyma. The entasis curve of the Didymean columns rises $4.65 \mathrm{~cm}$ over a built shaft length of approximately $18 \mathrm{~m}, 1 / 400$ in relative terms, quite a prominent rise for an Ionic temple. ${ }^{14}$ While unusual for an Ionic temple of Hellenistic age, such a prominent rise in the curve was fitting to the Archaic-inspired design of Didymaeon,

\footnotetext{
12 Entasis and the verb enteinein are used as technical terms in both Greek geometry and Greek optics.

13 Wilkins (1812), departing with a similar assessment soon discovered entasis at the Parthenon.

14 The first ancient Greek working drawing of an entasis is observed on the unfinished walls of the temple of Apollo at Didyma. For the discovery, see Haselberger (1980), pp. 191-215; specifically for the scale lines of drawing of entasis see Haselberger (1996), p. 165 with n. 55.
} 


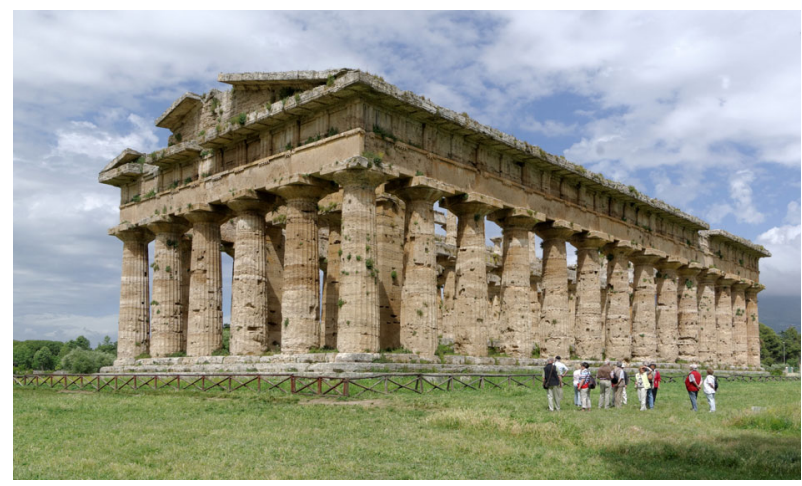

Fig. 8 The Temple of Apollo at Paestum, c. 460 BCE @Creative Commons

well-known for its intentionally unfinished qualities (Soyöz 1999). Similarly unusual for a temple of the Hellenistic age was its dense intercolumniation, which is the subject of the following section.

\section{Proportional Design}

The erasure of the sculptural quality of the Greek temple was not only achieved by curvature and entasis but also the contraction, contracturae of the column shaft diameter. Along with contracturae, Vitruvius also details the inclination of columns (3.5.4), a deviation from the strict vertical, achieved by diminishing, reducing or "contraction" of the primary width of an element from bottom to top, thus inclining its surfaces. In specific terms, Vitruvius (3.3.12f.) deals with the various fractions of lower shaft diameters that must be used for the upper diameter, depending on the absolute height of the column as it appears to the eye of a beholder. A different, fourth group of refinements is formed by the slight enlargement of architectural elements relative to what is understood as regular. Thus wider intercolumniations should result in thicker column shafts, adaugendae sunt, as Vitruvius points out (3.3.11) since the space would reduce their thickness for the eye; and for the same reason, he adds, corner columns, too, should have a "increased" diameter, enlarged by one fiftieth of the regular diameter. With this, an admittedly rather wide definition of optical measures emerges. Optical measures, the concept of detractions et adiectiones, include the addition or subtraction of a relatively small amount to or from an architectural element of much larger dimensions to adjust the proportioned dimensions of the work in question.

Also mentioned by Philon before Vitruvius, the method of "adding and subtracting to and from the masses" was actually used to alter proportions to achieve a planar rather than a sculptural expression, and a shift in temple architecture from the Classical to Hellenistic period. As opposed to Classical temples, the proportional relationships of Hellenistic temples are so articulated that they became purely space definers rather than sculptural entities. This trend had 
already started in Athenian temples of the late-Classical period. Vincent Scully observed revolutionary transformations in the proportional system of the Propylaia columns (Scully 1979, p. 199). According to Scully, the experience of the Propylaia is essentially volumetric, of bound space, which the solids are intended to frame. The thinner columns are now positively seen as structural posts creating a space, and the high entablature, viewed from below, comes into proportion with the columns.

H. S. Büsing conclusively proves in his study on Mnesikles' Propylaia (438-431 BC) that the architect consciously modified the proportions of the columns in consideration of their appearance to the viewer [1984, pp. 57-62]. He identifies three groups of columns according to their size and position: the main columns on the entry front in the west, steeply elevated above the approaching visitor; the columns on the inner, eastern front mirroring the entry front, yet in a slightly depressed position; and thirdly, the wing columns on both sides of the entry front, about $50 \%$ smaller than the front columns. The different visual appearance of these columns, due to position and size, corresponds to their proportional design. Büsing observes that the adjustments are especially apparent in the exterior Doric columns of the building. The eastern front was treated distinctively probably because it was the primary view that the building presented to the beholder. The main columns on the eastern front were not only placed at a higher position but were also made longer than the wing columns and their counterparts on the other side. The elongation of the columns combined with the steeper angle of view due to their taller size, compensates for the distortions caused by their height. Modified, too, is the height of the entablature, which is proportionally higher over the main columns than over the wing columns. The adjustments introduced to the proportions of the Propylaia mark a significant turning point comparable to Lysippos' proportional system, which is meant to make the figures seem tall so that they appear "correct" to the human eye. The elongated proportions of the Propylaia likewise make the building appear taller, leaner and adjusted horizontally thanks to the selectively applied curvature and entasis.

Tempering the monument's symmetriai to the beholder's vision consisted of a two-step process (Büsing 1984; Haselberger 1999). Before the application of optical refinements (i.e. entasis and curvature), the architect first applied the "ideal" symmetries to the conditions of appearance. Secondly, the appearance of the temple was further refined with the application of the counter-measures. This method resulted in a new sensibility towards an elegant aesthetic; the sculptural quality of the Classical temple was drained in favor of painterly (i.e. non-structural) appearances of structural elements. While this new aesthetic might have been actualized in the Propylaia by the two-step process, later Hellenistic architects seem to have invented a more straightforward approach. An abstract proportional system which achieves an elegant style was developed by Pytheos, the architect of the temple of Athena at Priene, who is also said to have written a commentary on the proportions of the same temple (Fig. 9).

Unfortunately, it is impossible to know how Pytheos legitimized his canon of proportions, as his commentary on the Temple of Athena did not survive beyond the quotations provided by Vitruvius. The remains of the Temple of Athena, however, 


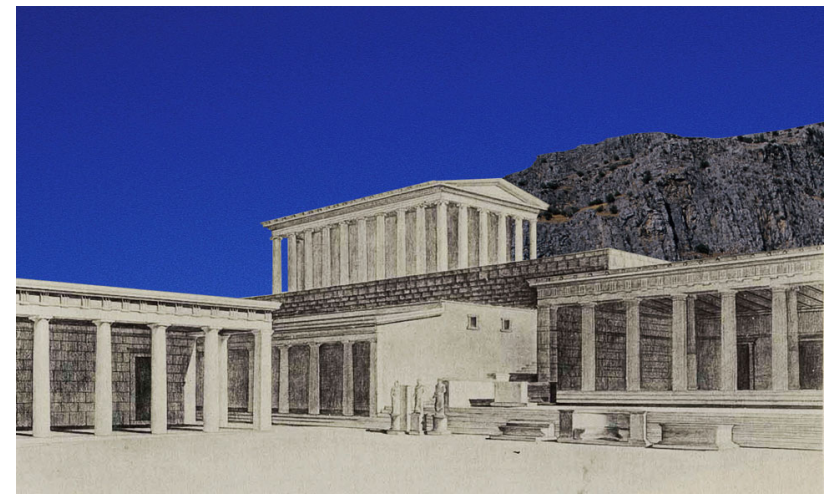

Fig. 9 The Temple of Athena at Priene, drawing modified from Doxiadis, photo collage by Hasan Gökbora

suggest that he might have translated the Doric principles into an Ionic style and adjusted the proportions of his temple accordingly (Koenigs 1999, pp. 139-154). The substantial remains of the temple of Athena at Priene (Fig. 9) suggest that its proportions were generated as a result of a generalized mathematical abstraction. Built on a grid plan, the temple of Athena displayed a precisely calculated order, which seems to have been crafted with the intention of creating an elegant style with elongated proportions, i.e. thin columns, high entablatures, inspired by the aesthetic sensibility developed in Mnesikles' Propylaia.

As the elegance of the Propylaia was created in response to its higher placement above the entrance stairs, the elongated proportions of the Temple of Athena at Priene were essential to its visibility from the altar at the agora. From this viewpoint, the temple was meant to be seen, as a "foil to the solid mass of the cliff" (Scully 1979, p. 198) playing out the natural [real] versus man-made [illusory] duality. In order to create such a contrast between the man-made elegance of the Ionic temple and natural roughness of the rock surface, Pytheos had to elongate the proportions of the temple so that he could "compensate" for their diminutions caused by its higher and more distant placement in relation to the agora.

A later Hellenistic temple, which seems to have been inspired by the proportional relations developed for the Temple of Athena, is the well-known pseudo-dipteral Temple of Artemis Leukophryene at Magnesia on the Meander (Hoepfner 1997). It was designed by the famous Hellenistic architect Hermogenes, whom Vitruvius credited as the inventor of the pseudo-dipteral ground plan for temples (Vitruvius 3.3.8-9). This attribution was not exactly true, since there are examples of pseudodipteral plans in Sicilian Doric temples as early as the Archaic period (e.g. 'Temple G' at Selinus). However, Hermogenes may have been the first to apply it to the Ionic order, and it is most probable that he was the first to rationalize its use. Hermogenes' refashioning of the pseudo-dipteral plan makes sense considering the Hellenistic tendency towards volumetric design. The removal of the interior row of columns from the dipteral arrangement increases the space between the cella wall and the 
colonnade, contributing to the Hellenistic trend of conceiving the temple as a space binding edifice.

Hermogenes' innovations in the design of the Temple of Artemis at Magnesia were not limited to the introduction of the pseudo-dipteral plan (Fig. 10). He also introduced a constructed environment within which the temple is presented to the viewer. Unlike the Temple of Athena at Priene, which was presented as a sculptural self-sufficient entity against the sacred landscape, the Temple of Artemis at Magnesia acquired its urban environment, a man-made rectangular framework enclosed with stoas and a propylon. The rectangular framework further accentuated the depth perception rather than mass, consequently increasing the painterly effect.

The architect also very carefully calculated the proportions and the geometrically structured views of the temple to be seen specifically upon entrance to the precinct (Schmaltz 1995, p. 133 ff). From this vantage point, the layout and the sizes of the altar and temple were arranged in such a way that the three-meter high reliefs of the altar were exactly aligned with the width of the temple. While the altar figures created the impression of "real" men, contrasts between tactile qualities of different architectural elements might have been employed to reproduce the natural versus man-made dichotomy in new forms, i.e. with real versus illusory or real versus more-real. The colonnades with their shady effects, for instance, stood against the mass of the marble relief. Likewise, the wide openings in between narrow and tall columns of the pseudodipteral temple front added to the contrast between light and dark. Contrasts were created through manipulating the proportions of not only architectural elements, but also the details. Particularly, the egg motifs of the Ionic capital were deeply carved and the volutes were given edged instead of round forms (Hoepfner 1997, p. 113).

Hermogenes thus invented new forms, refinements and rules for the Ionic order and thereby exerted a significant influence on the architecture of his time. He prescribed a complex system of proportional relationships for the proportions of the peripteral colonnades of the temples (Vitruvius, 3.3.1-10). His system was based on the principle that there should be a consistent relationship between the interaxial of a colonnade and the height of its column: the narrower the interaxial, the taller the column and, conversely, the wider the interaxial, the shorter the column. Using the diameter of a single column as a module, Hermogenes devised and named five specific types of proportional relationship: pycnostyle (the dense columnar system),

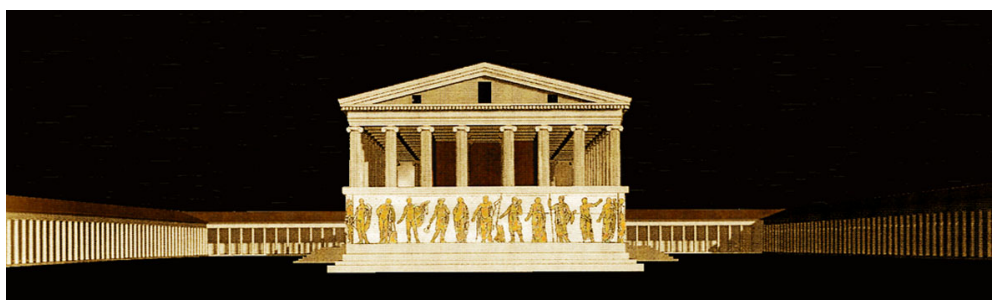

Fig. 10 Temple of Artemis at Magnesia, Early 2nd century BCE drawing modified from Schmaltz, photo collage by Hasan Gökbora 


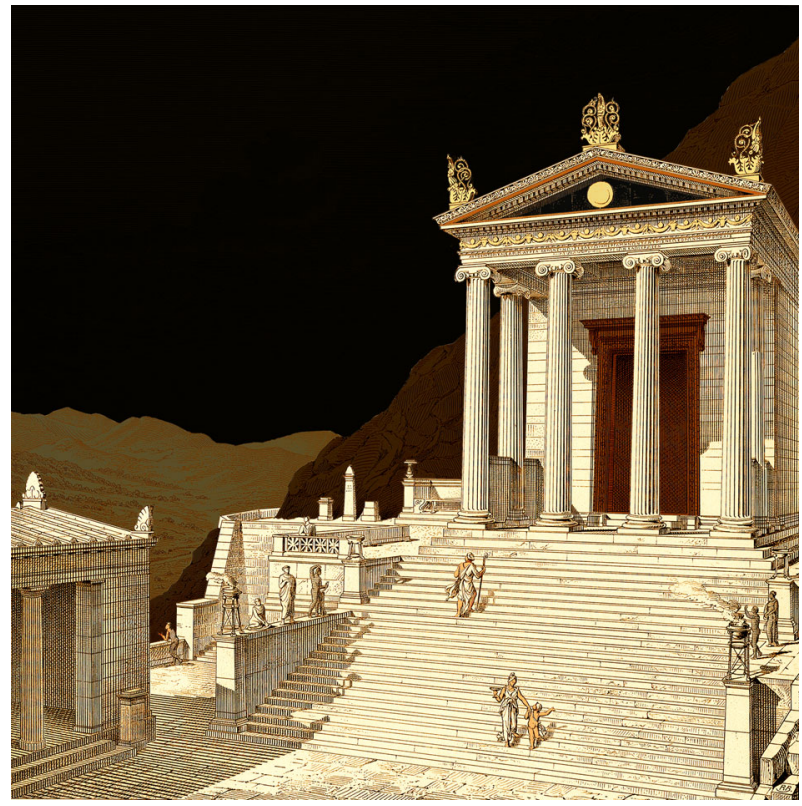

Fig. 11 The Temple of Dionysus at Pergamon, drawing modified from Bohn by Hasan Gökbora

systyle (the close system), diastyle (the open system), araeostyle (the far apart system) and eustyle (the fair or harmonious system).

The influences of Hermogenean innovations are especially visible in the design of the Ionic buildings of the High Hellenistic period in Pergamon, such as the Temple of Dionysus on the theater terrace (Fig. 11). ${ }^{15}$ The temple of Dionysus at Pergamon was the largest temple in Pergamon, designed with a pseudodipteral plan, conforming to a systylos system. Like the temple of Artemis at Magnesia, the temple of Dionysus was primarily designed as a space-defining edifice. The extraordinarily wide spacing of its columns $(1.13 \mathrm{~m}$.) corresponds to the width of its door, emphasizing its volumetric design. The frontal view of the temple of Dionysus creates dynamic contrasts between the tactile qualities of different architectural elements. Its high podium and elegant colonnades with shaded effects, for instance, stood against the dramatically receding colonnade of the stoas that framed it on both sides. The dramatic mass of the hill behind further complemented such anamorphic effects and coordinated the temple with the ideal viewing angle.

Pytheos and Hermogenes thus were the Hellenistic successors of the LateClassical architects, who innovated planar expressions of spatial depth while claiming to design their buildings with respect to the human eye, a century before Vitruvius recommended the practice to Roman architects. The traces of such perspectival practice, attention to what can be seen from a particular viewpoint

\footnotetext{
15 According to Hoepfner (1997, pp. 46-53), the temple R in the Gymnasium might have been designed by Hermogenes.
} 
given distance and angle, are visible on every monumental example from the Hellenistic period. That the Hellenistic period was a rich and vital period for perspectival modalities in all media proved that perspectival technology was exploited to create a painterly style fitting with the theatrical atmosphere.

\section{Conclusion}

So far, I have discussed applications of ancient perspective in the medium of architecture. Less documented due to the nature of evidence are the developments in painting, especially murals which inspired architectural tendency for the "painterly" expression. While architects were experimenting with finding painterly means of expressions via optical measures, painters made architecture their primary subject matter. Hence, followed the perspectival revolution in painting. The practice of perspective was indeed connected in its architectural and painterly applications in the medium of skenographia, scene painting which came to mean ancient perspective (Panofsky 1991 [1927], pp. 37-45; Pérez Gómez and Pelletier 1997, pp. 97-105).

An early synthesis of the pictorial and architectural is visible, for instance, in a theatrically inspired scene on a vase (Würzburg) fragment, dated c. 360-350 BCE (Fig. 12). In this image we see a projecting kiosk in a feigned depth framing a halfopen door. ${ }^{16}$ What type of building was such a façade supposed to evoke? The scholarly effort to propose a definitive model for the image fails, since the vase painter could draw inspiration from varied sources: theatrical, painterly and architectural. The picture presents an eclectic confabulation of evocative elements that might recall an actual palace-façade or stage building, or an architectural representation, i.e. a painted palace-façade displayed on a stage building. ${ }^{17}$ In other words the overlap of the architectural and painterly on the vase painting already indicates the blurring of the boundaries between architectural and painterly on the stage building.

The Würzburg painter's concern with the architectural is most conspicuously implied by various means developed to represent space or depth; the female in the background is painted smaller than the two male figures in the foreground. Another indication for the spatial thinking is given by the orthogonals constituting the ceiling of the kiosk, recalling an axonometric construction. Yet the architectural considerations do not take over the rest of the composition. The depth is negated while surface is emphasized for instance with the awkwardly flat frame in between the projecting wings of the façade. Conforming to Vitruvius' description of the scenery of stage, the vertical and plane surfaces constituting the kiosk prominentia, project forward, while the flanks of the stage door abscedentia, recedes into the background, further reminding the viewer of the materiality of the vase's surface

\footnotetext{
16 Erika Simon (1982, p. 24) identifies the scene as Iason's arrival in Iolkos and confrontation with his uncle King Pelias.

17 Scholars have proposed several models. M. Robertson (1979, p. 164) sees it as a palace-façade; both Heinrich Bulle (1934, pp. 3ff. Figures 1-5, pls. I-II) and Erika Simon [1982, p. 24] believe that the Tarentum piece does not represent an actual stage building but a stage painting, skēnographia.
} 


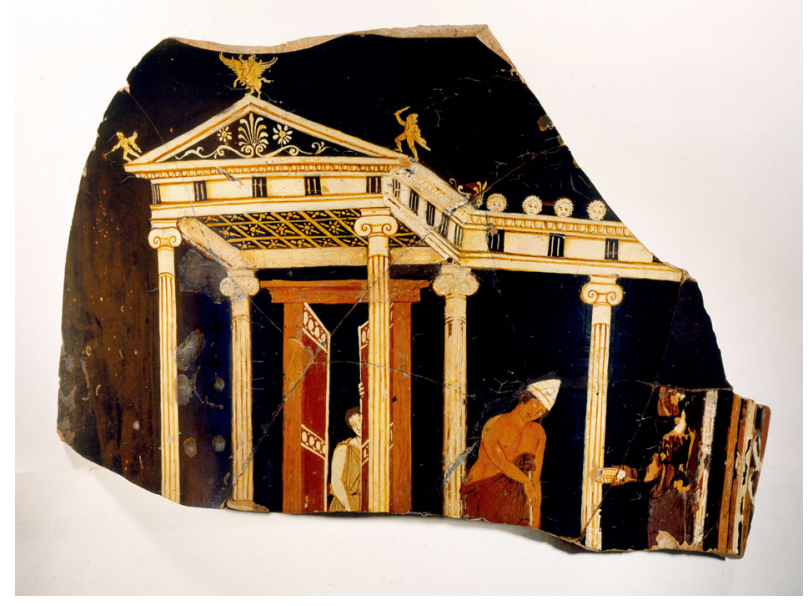

Fig. 12 The Vase painting from Tarentum, c. 360-350 (CMartin von Wagner Museum

(On Architecture VII. Praef11). ${ }^{18}$ Hence the vision was made to fluctuate in and out of illusionistic space. Codifying the viewing as a dynamic action between object and subject, such a spatial construction manifestly disrupts spatial coherence. By keeping the paradox of the surface and depth intact within the spatial construction, ancient perspective constructs a vision both tangible and visible; an artistic reality that openly acknowledges its ambiguity between architectural and painterly.

Application of such a technique to the stage imagery would not only enable a creative synthesis between architecture and image but also contribute to the polyvalence of stage design. Scene painting as a three-dimensional architectural representation would have juxtaposed the architecture (of the stage) with its representation (painting) and thereby invited the viewer to question the "reality" of the perceived world or the related issue of his/her vision's capacity for perceiving the "truth". In a world where philosophical tropes on the reality of illusion were common intellectual currency, the stage designer would likely have blurred the boundaries between architectural and painterly with the three-dimensional images, hence recreating the paradox of real and illusory.

Power is embedded within this discourse in its political manifestations. ${ }^{19} \mathrm{We}$ can observe this the most clearly in the perception of scene painting around which the discourse crystallized. Ancient testimonies exemplify how scene painting as a spatial medium acted both as an effect and instrument of wielding power. Anaxarkhos (the fourth-century Demokritean philosopher, who went to India with Alexander) compared ordinary existence to the painting on the $s k \bar{e} n \bar{e}$ as early as the

\footnotetext{
${ }^{18}$ For an understanding of the spatial conception of ancient perspective see; Panofsky (1991(1927), pp. 27-36) and Pérez-Gomez and Pelletier (1997, pp. 97-105). A recent study on ancient perspective Senseney (2011) is misleading in retrojecting later perspectival practices, i.e. linear perspective, onto classical antiquity.

19 For a comprehensive discussion of the political implications of perspectival developments in the Hellenistic age, see Soyöz [2010, passim].
} 
fourth century BCE. He meant that ordinary things are illusory, like the impressions encountered in sleep, or the painted façade representing a theatrical house (Sextus Empiricus, Adversus Mathematicos 7.I.88). In another anecdote narrated by Plutarch (Aratos 15), Antigonos Gonatas tried to alienate Aratos from Ptolemy III by reminding him that all the impressive power of the Ptolemaic king was the result of careful play acting and painted scenery. Similarly, the perception of the skene, and its design as a source of deception becomes clear when Plutarch praises the Spartiates for having neither halls nor any other kind of building for their assembly. Taking it for granted that a theatre was occasionally used for the meeting of the assembly, Plutarch explains that "when those who have come together gaze during the assembly upon statues and paintings or proscenia of theaters, or extravagantly decorated roofs of council halls, they become foolish, vain, and empty-headed" (Plutarch, Lycurgus, 6) (Translation: Chaniotis 1997), p. 224.

This very confusion caused by the collision of architecture and the painterly in the medium of scene painting was consecutively reproduced in the "real" world through an intermingling of the two. Optical knowledge not only enabled the architects to legitimize their favored "picturesque" aesthetic taste on the basis of optical science but also effectively blurred the distinction between architectural and painterly, hence the perceived truth and reality thereby caused an enchanting paradox. In conclusion, the optical knowledge wielded through architecture and painting became powerful twice. Firstly, because architects and painters produced an encompassing spatio-visual discourse on truth and illusion a paradox was created, and second by means of optical science they legitimized their "true" product, which is then used in the service of imperial Hellenistic ideology.

\section{References}

\section{Ancient Sources}

Aristotle. Poetics. Trans. by Stephen Halliwell. The Loeb Classical Library. Cambridge, Mass.: Harvard University Press, 2005.

Plato. Sophist. Trans. by Harold North Fowler. The Loeb Classical Library. Cambridge, Mass.: Harvard University Press, 2005.

Pliny Natural History. Trans. by H. Rackham. The Loeb Classical Library. Cambridge, Mass.: Harvard University Press, 2005.

Vitruvius On Architecture. Trans by Frank Granger. The Loeb Classical Library. Cambridge, Mass.: Harvard University Press, 2002.

\section{Secondary Literature}

Bek, L. 1985. Venusta Species. A Hellenistic Rhetorical Concept as the Aesthetic Principle in Roman Townscape. Analecta Romana Instituti Danici 14: 139-148.

Bohn, R. 1896. Die Theater-Terrasse. Berlin: Altertümer von Pergamon Bd4.

Bulle, H. 1934. Eine Skenographie. Berlin: De Gruyter.

Büsing, H. S. 1984. Optische Korrekturen und Propylaen-Fronten. Jahrbuch des Deutsches Archaologischen Instituts 99: 27-214. 
Chaniotis, A. 1997. Theatricality Beyond the Theater. Staging Public Life in the Hellenistic World. Pallas 47: 219-259.

Choisy, A. 1999. Histoire de l'Architecture (1899). Paris: Bibliothèque de l'Image.

Doxiadis, C. A. 1972. Architectural Space in Ancient Greece. Cambridge, Mass.: MIT Press.

Edwards, C. M. 1996. Lysippos. In: Personal Styles in Greek Sculpture, eds. O. Palagia and J. J. Pollitt. New York: Cambridge University Press.

Filseck, K. M. v. 1988. Der Apoxymenos des Lysipp. Ph.D. thesis, Bonn.

Goodyear, W.H. 1912. Greek Refinements: Studies in Temperamental Architecture. London: Yale University Press.

Haselberger, L. 1980. Werkzeichnungen am Jüngeren Didymeion. Vorbericht. Istanbuler Mitteilungen 30: $191-215$.

Haselberger, L. 1996. Eine Krepis von 200 Fuß Gestreckter Länge. Istanbuler Mitteilungen 46: 165.

Haselberger, L. 1999. Appearance and Essence: Refinements of Classical Architecture-Curvature. Proceedings of the Second Williams Symposium on Classical Architecture (University of Pennsylvania, Philadelphia, April 2-4, 1993). Philadelphia: University Museum, University of Pennsylvania.

Hoepfner, W. 1997. Hermogenes und Epigonos. Jahrbuch des Deutsches Archaologischen Instituts 112: 109-148.

Koenigs, W. 1993. Planung und Ausbau der Agora von Priene. Istanbuler Mitteilungen 43: 381-397.

Koenigs, W. 1999. The Temple of Athena Polias at Priene: Doric Architecture in the Guise of Ionic? In: Appearance and Essence: Refinements of Classical Architecture-Curvature. Proceedings of the Second Williams Symposium on Classical Architecture (University of Pennsylvania, Philadelphia, April 2-4, 1993), ed. L. Haselberger, 139-154. Philadelphia: University Museum, University of Pennsylvania.

Leiber, J. 1993. Paradoxes. London: Duckworth.

Marsden, E. 1971. Greek and Roman Artillery: Technical Treatises. Oxford: Oxford University Press. Moreno, P. 1973. Testimonianze per la Teoria Artistica di Lisippo. Treviso: Libreria editrice Canova. Panofsky, E. 1991. Perspective as Symbolic Form (1927). Cambridge, Mass.: Zone Books.

Pérez Gómez, A. and L. Pelletier 1997. Architectural Representation and the Perspective Hinge. Cambridge, Mass.: MIT Press.

Pollitt, J. J. 1974. The Ancient View of Greek Art: Criticism, History, and Terminology. New Haven: Yale University Press.

Pollitt, J. J. 1986. Art in the Hellenistic Age. Cambridge: Cambridge University Press.

Robertson, M. 1979. Greek Painting. Geneva: Skira

Schmaltz, B. 1995. Aspectus und Affectus-Hermogenes und Vitruv. RM [Mitteilungen des Deutschen Archäologischen Instituts, Römische Abteilung] 102: 133-140.

Scully, V. J. 1979. The Earth, the Temple, and the Gods: Greek Sacred Architecture. New Haven: Yale University Press.

Senseney, John R. 2011. The Art of Building in the Classical World: Vision, Craftsmanship, and Linear Perspective in Greek and Roman Architecture. Cambridge; New York: Cambridge University Press.

Simon, E. 1982. The Ancient Theatre. London: Methuen.

Soyöz, U. 1999. The Temples of Apollo at Didyma and Klaros as Centers of Oracular Activity. Master thesis, METU, Ankara.

Soyöz, U. 2010. Drama on the Urban Stage. Architecture, Spectacles and Power in Hellenistic Pergamon. $\mathrm{PhD}$ Thesis. The University of Texas, Austin.

Wilkins, W. 1812 The Civil Architecture of Vitruvius. London: Thomas Davison for Longman, Hurst, Rees, Orme, and Brown.

Winckelmann, J. 1964. Anmerkungen über die Baukunst der Alten (1762). Leipzig: Heitz.

Ufuk Soyöz (Ankara, 1975) is an architect and architectural historian specializing in the history and theory of architecture with a particular focus on ancient Greek and Roman art, architecture and visual culture. Ufuk Soyöz currently teaches in the Department of Interior Architecture and Environmental Design at Istanbul Kemerburgaz University. Before coming to IKBU, she taught for two years in the Department of Art History at Rice University. She received an undergraduate degree in architecture and an MA in architectural history at Middle East Technical University in Ankara before completing her dissertation in the department of History of Art at the University of Texas at Austin. 